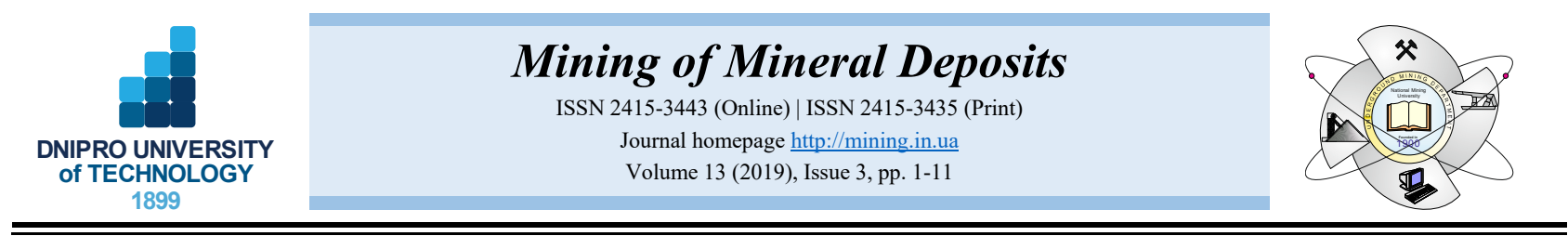

UDC 622.281 .23

https://doi.org/10.33271/mining13.03.001

\title{
GENERALIZATION OF TRENDS IN THE INFLUENCE OF GEOMECHANICS FACTORS ON THE CHOICE OF OPERATION MODES FOR THE FASTENING SYSTEM IN THE PREPARATORY MINE WORKINGS
}

\author{
I. Kovalevska ${ }^{1 *}$, M. Zhuravkov², V. Chervatiuk ${ }^{3}$, O. Husiev ${ }^{4}$, V. Snihur ${ }^{5}$ \\ ${ }^{1}$ Dnipro University of Technology, Dnipro, Ukraine \\ ${ }^{2}$ Belarusian State University, Minsk, Belarus \\ ${ }^{3}$ LLC "DTEK Energy", Kyiv, Ukraine \\ ${ }^{4}$ MM "Dniprovske", PJSC "DTEK Pavlohradvuhillia”, Pavlohrad, Ukraine \\ ${ }^{5}$ MM “Heroiv Kosmosu”, PJSC "DTEK Pavlohradvuhillia”, Pavlohrad, Ukraine \\ *Corresponding author: e-mail kovalevska_i@yahoo.com, tel. +380567560047,fax: +380563742184
}

\begin{abstract}
Purpose. Substantiation of the mechanism of loading the preparatory mine working support to optimize its deformation-strength characteristics based on the calculation of the stress-strain state of the "massif - support" system. Improving the cost effective technologies for fastening and maintaining the preparatory mine workings.

Methods. The analysis of the elements interaction modes of the "massif - support" system has been performed by the two-parameter diagram for optimizing the deformation-strength characteristics of the rock massif and the preparatory mine workings support using the research results of the stress-strain state of a system by means of finite element method. A comparison has been made of computational experiment with mine instrumental observations.

Findings. The geomechanical model of the computational experiment on the choice of operation modes of the fastening system, as well as the methodology of the approach to optimize the process of interaction between the massif and the support have been substantiated. The analysis of search patterns for the rational deformation-strength characteristics of the fastening system in the preparatory mine working, taking into account the influence of the main geomechanics factors on this process, has been developed and performed.

Originality. The patterns have been established of the geomechanics factors influence on the choice of rational operation modes of the load-bearing elements of the fastening system and the support in general based on research of the stress-strain state of the "massif - support" system. The optimization principles of interaction based on the analysis of a two-parameter interaction diagram have been substantiated.

Practical implications. The wide perspective has been substantiated for strengthening the soft rocks in reusable preparatory mine workings with combined roof-bolting systems, which makes possible to realise the resource-saving conditions of maintenance. The calculations have been made with account of the optimization criteria for interaction of massif and support.
\end{abstract}

Keywords: rock massif, preparatory mine working, support, deformation, loading, stability, geomechanics factors

\section{INTRODUCTION}

The studies, conducted on certain examples of the stress-strain state (SSS) calculation, have revealed the tendencies of relation between the diagrams elements state for maintaining the preparatory mine workings with the most influencing geomechanics factors (Bondarenko, Kovalevs'ka, \& Cherednychenko, 2010; Kovalevska, Barabash, Husiev, \& Snihur, 2018; Małkowski, Ostrowski, \& Brodny, 2018). For each of them, the mining and geological situation of maintaining the drift can be divided into "favourable" (for example, the shallow depth of development, increased rock hardness, etc.) (Małkowski \& Ostrowski, 2017) and "complex", which is characterized by the development of high rock pressure. In this regard, it is very important to find, assess and summarize the patterns of change in rational operation modes (both for the fastening system as a whole and its separate elements) in the variation range of geomechanics parameters and the corresponding mining and geological situation from favourable to complex (Bondarenko, Kovalevs'ka, Svystun, \& Cherednichenko, 2013; Arshadnejad, 2018).

(C) 2019. I. Kovalevska, M. Zhuravkov, V. Chervatiuk, O. Husiev, V. Snihur. Published by the Dnipro University of Technology on behalf of Mining of Mineral Deposits. This is an Open Access article distributed under the terms of the Creative Commons Attribution License (http://creativecommons.org/licenses/by/4.0/),

which permits unrestricted reuse, distribution, and reproduction in any medium, provided the original work is properly cited. 
On the basis of these patterns, a set of recommendations is being defined on the choice of a rational diagram for maintaining the extraction mine working with account of the predicted changes in the mining and geological environments along its length and in time of operation.

The primary focus, as before (Bondarenko et al., 2017; Kovalevska, Barabash, Husiev, \& Snihur, 2018; Bondarenko, Kovalevska, Symanovych, Husiev, \& Snihur, 2019), is on the parameters describing the fastening system operation, that is, its deformation-strength characteristics $q(u)$. With the use of concepts represented in (Kovalevska, Barabash, Husiev, \& Snihur, 2018), an attempt to their further development was made in terms of search a rational function $q(u)$ in the process of changing the mining and geological environments for maintaining the preparatory mine working.

\section{THE STUDY OF INTERACTION WITH A HOMOGENEOUS MASSIF OF THE YIELDING SUPPORT IN A SINGLE MINE WORKING}

A diagram is constructed in Figure 1 of the loading factors development in the fastening system when its yielding property value is changed for two fixed environments: favourable (the index ' $f$ ") and complex (the index " $c$ "). The change in mining and geological environments is conditioned by various geomechanics factors: transformations of the coal-bearing massif structure (Bondarenko, Kovalevs'ka, \& Fomychov, 2012), the replacements of separate lithotypes (Symanovych, Demydov, \& Chervatuk, 2013), areas of increased inflow of water (Sadovenko \& Tymoshchuk, 2013; Ivšinović, 2017; Menshov \& Sukhorada, 2017) or intense fracturing (Bondarenko, Simanovich, Kovalevska, Fomichov, \& Serdiuk, 2007; Kovalevska, Symanovych, \& Fomychov, 2013; Masny, Prusek, \& Mutke, 2017; Lozynskyi, Saik, Petlovanyi, Sai, \& Malanchuk, 2018); depending on their combination (Madziarz, 2015), there is a different degree of worsening in mining and geological environments. Several fixed positions have been considered (numbered in I-IV) of the process of the load formation on the fastening system (Fig. 1), which are different in value of its permissible yielding property $u_{y}^{I}, u_{y}^{I I}, u^{I I I}$ and $u^{I V}$.

The first position I is characterized by the fact that the permissible (or construction) yielding property $u_{y}^{I}$ of the fastening system is less than the optimal value in favourable environments $\left(u_{y}^{I}<u_{A}^{f}\right)$, which is determined by the point of $1 f$ and $2 f$ lines intersection. The reduced yielding property of this fastening system predetermines the value $P_{f}^{I}$ of load in favourable environments as the point of intersection of $1 f$ line and $u_{y}^{I}$ vertical (Fig. 1). The value $P_{f}^{I}$ is greater than the optimal $P_{A}^{I}$ (or the minimum possible) and this excess is conditioned by the increased rigi-dity of the fastening system, which is confirmed by the examples represented earlier for calculating the SSS of fastening system (Bondarenko, Kharin, Antoshchenko, Gasyuk, 2013; Bondarenko et al., 2017). The same examples show that when worsening the mining and geological environments (due to various factors), the state of more rigid fastening elements becomes much more complicated up to loss of stability. Indeed, if to extend the vertical from $u=u_{y}^{I}$ to the intersection with $1 c$ line, then we obtain the load value $P_{c}^{I}$, which many times exceeds the value $P_{f}^{I}$.

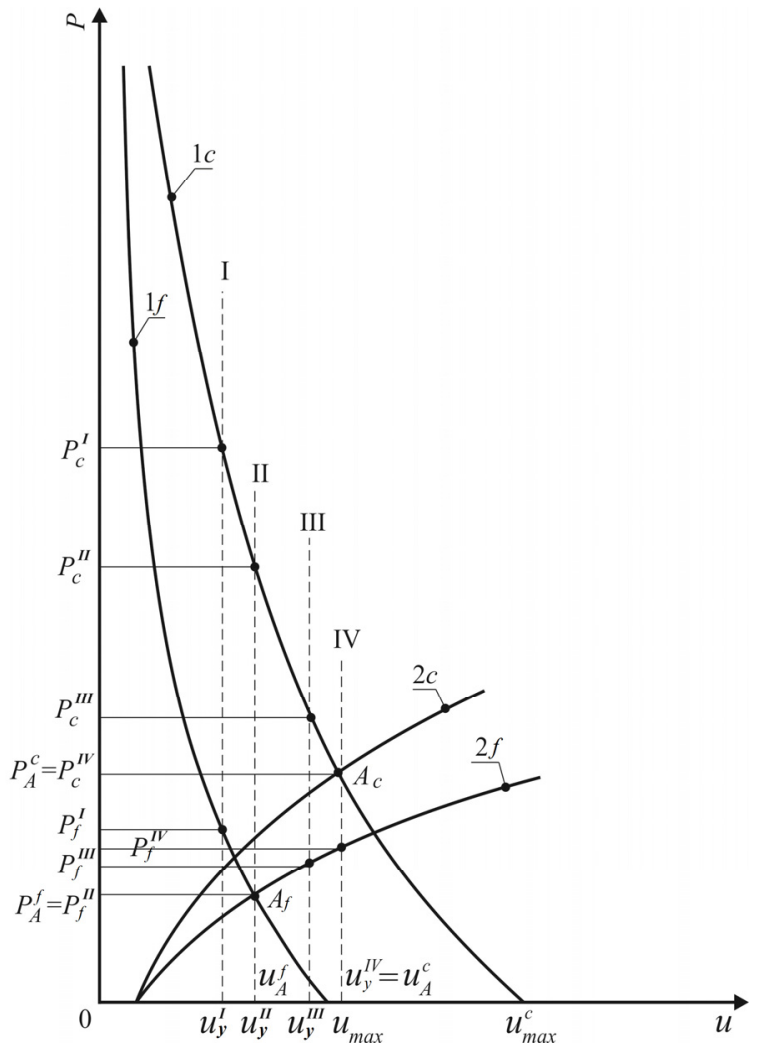

Figure 1. The search pattern for rational deformationstrength characteristics of the fastening system when changing the mining and geological environments of mine working maintenance: $1 f$ and $1 c$ the deformation-strength characteristics of the weakening massif on the mine working contour in favourable $(f)$ and complex (c) mining and geological environments; $2 f$ and $2 c$-the deformationstrength characteristics of the rocks of dome of natural equilibrium; I, II, III and IV-the permissible yielding property of the fastening system

Thus, the existing concepts of the influence of the deformation-strength characteristics of the fastening system on the process of its loading are in complete agreement with the SSS calculation results of the elements for maintaining the preparatory mine workings (Bondarenko, Simanovich, Kovalevska, Fomichov, \& Serdiuk, 2007; Tereschuk, Grigoriev, Tokar, \& Tikhonenko, 2014; Aitkazinova, Soltabaeva, Kyrgizbaeva, Rysbekov, \& Nurpeisova, 2016; Masny, Prusek, \& Mutke, 2017; Khalymendyk, \& Baryshnikov, 2018)

The reduce in the load on the fastening system to the minimum possible value $P_{A}^{f}$ (in favourable environments) involves an increase in the yielding property to a value $u_{y}^{I I}=u_{A}^{f}$ determined by the point $A_{f}$ of intersection of lines $1 f$ and $2 f$. The second position II is optimal in favourable environments, as well as the deformationstrength characteristics of the fastening system, which passes through the point $A_{f}$. With the complication of mining and geological environments, an increase in the permissible yielding property of the fastening system is required: the optimal value $u_{A}^{c}$ is determined by the point $A_{c}$ of intersection of $1 c$ and $2 c$ lines. When restricting the yielding property by the value $u_{A}^{f}$, the loading on the fastening system (in complex mining and geological environments) increases many times to the value $P^{I I}$. 
Here it is necessary to pay attention to the value of the load decrease in the range of the increase in yielding property from $u_{y}^{I}$ to $u_{y}^{I I}=u_{A}^{f}$ : in favourable environments, the difference $P_{f}^{I}-P_{f}^{I I}$ is significantly less than the load $P^{I}{ }_{c}-P^{I I}{ }_{c}$ decrease in complex mining and geological environments, that is, when worsening, the fastening system is more sensitive to changes in the value of yielding property.

The third position III is characterized by the yielding property $u^{I I I}$ of the fastening system, which takes an intermediate value $u_{A}^{f_{A}<u^{I I I}}<u_{A}^{c}$ between the optimal yielding property in favourable and complex mininggeological environments. The load $P_{f I I}$ in favourable environments is determined by the point of intersection of vertical $u=u^{I I I}$ with $2 f$ line, since the yielding property of the fastening system has exceeded the optimal value $u_{A}^{f}$. Thus, the formed load $P_{f}^{I I I}$ takes an intermediate position $P_{A}^{f}<P_{f}^{I I I}<P_{f}^{I}$, and the degree of its excess over the optimal load $P_{A}^{f}$ is estimated at only several tens of percent. It follows that even in favourable conditions it is more expedient (from the point of view of load formation) to increase the construction yielding property of the fastening system as compared with providing rigidity to its work (position I). This positive moment is increased with worsening the mining and geological environments for the mine working maintenance (Fig. 1).

The value $u^{I I I}{ }_{y}$ is less than the optimal value $u_{A}^{c}$, so the load $P^{I I I}{ }_{c}$ is determined by the intersection of the vertical with $1 \mathrm{c}$ line. The value $P^{I I I}{ }_{c}$ is significantly lower than in positions I and II; the gap is also reduced between the load values in favourable and complex environments. In such a way, if to compare the positions of I, II, III with each other by a value of the load in complex environments, then the conclusion $\left(P^{I I I}{ }_{c}<P^{I I}{ }_{c}<P_{c}^{I}\right)$ is evidenced about the preference for increased yielding property $u^{I I I}$ of the fastening system. In combination with a moderate difference $P^{I I I} f-P_{A}^{f}$, it is fair to say that the variant of increasing the yielding property of the fastening system is sufficiently competitive with a significant probability of complicating the mining and geological environments of maintenance along the length of the preparatory mine working.

The fourth position IV is characterized by the yielding property $u^{I V}$ equal to the optimal value $u_{A}^{c}$ for complex mining and geological environments, which is determined by the $A_{c}$ point of intersection of $1 c$ and $2 c$ lines; the minimum possible load $P^{I V}{ }_{c}=P^{c}{ }_{A}$ (Fig. 1) on the fastening system corresponds to it in these environments for the mine working maintenance. According to the load value $P^{I V}$, the value of yielding property $u^{I V}$ is the most expedient, since there is the following ratio $P^{I V}{ }_{c}<P^{I I I}{ }_{c}<P_{c}^{I}$. On the other hand, while maintaining the mine working in favourable environments, the fastening system with the yielding property $u^{I V}$ takes up a load $P^{I V}$ that exceeds insignificantly the value $P_{f}^{I I I}$, but is less than the value $P_{f}^{I}\left(P^{I I I}<P_{f}^{I V}<P_{f}^{I}\right)$, corresponding to a decreased yielding property of the fastening system. Consequently, in the areas of mine working with more favourable mining and geological environments, the increased yielding property of the fastening system does not cause a significant increase in a load.
Furthermore, it should be noted the reduction of the difference $P^{I V}{ }_{c}-P^{I V}$ in load values for complex and favourable environments while maintaining the mine working. Thus, the above analysis substantiates the conclusion on preference of the increase in yielding property of the fastening system in order to reduce the load in complex environments and eliminate the consequences of the probable worsening the mining and geological situation by the factor of its loading. However, the increase in the yielding property of the fastening system has a clear boundary: it should not exceed the optimal value $u_{A}^{c}$ for the complex environments of maintaining a certain mine working. The degree of complexity of these conditions is considered relatively favourable (standard) development of events and is predicted by aggregate influence of the main geomechanics factors on the activation of the rock pressure manifestations; that is, the difference between conventionally "complex" and "favourable" environments may be insignificant in one mining-engineering situation and, on the contrary, to be significant at a particular situation of maintaining the mine working.

In this sense of the interaction patterns of the operation modes of the fastening system and the rock pressure manifestations, with a corresponding range of changes in geomechanics factors of the mine working maintenance, the further development of concepts has been made in terms of taking into account the inhomogeneity of the coal-bearing massif.

The diagram of interaction of the mine working fastening system with a weakening surrounding massif is constructed on the assumption about its homogeneity and the absence of the stope works influence. On the one hand, this diagram is necessary for the understanding of the general trends in the development of the interaction process, but, on the other hand, its improvement is required for accounting of:

- the structure of coal-overlaying formation and mechanical properties of its lithotypes;

- stratification, weakening and collapse of rock layers under the influence of rock pressure anomalies conditioned by performance of the stope works.

\section{ANALYSIS OF THE INFLUENCE OF MINING AND GEOLOGICAL ENVIRONMENTS OF COAL-OVERLAYING FORMATION ON THE LOADING OF A SINGLE MINE WORKING}

First of all, on the diagram of a homogeneous massif (Fig. 2), an insight is provided into the thesis about the relativity of the difference between complex and favourable environments in terms of the interaction parameters of support and surrounding rocks. The diagram shows a family of lines (1', 1", 1'' and 2',2", 2"'), characterizing the different intensity of the rock pressure manifestations, which corresponds to certain mining and geological environments of mine working maintenance. These three pairs of lines make it possible to specify three variants of the change ranges in mining and geological environments $\left(Y_{I}, Y_{I I}\right.$, and $\left.Y_{I I I}\right)$ from favourable to complex (Figs. 3 and 4). 


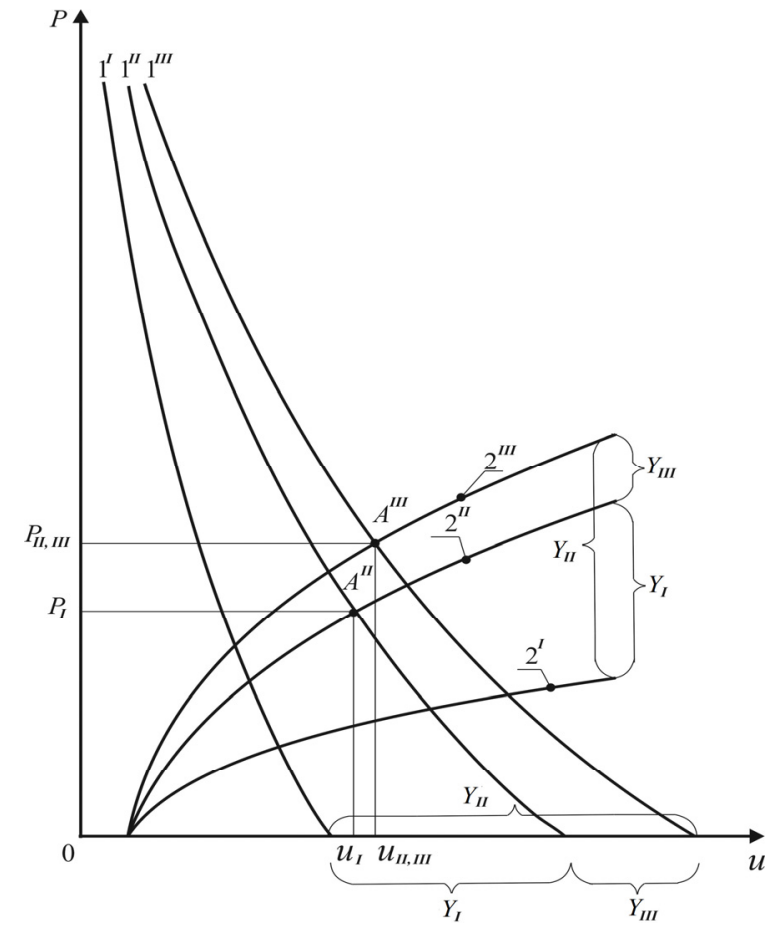

Figure 2. The diagram to the analysis of influence of the change ranges $Y_{I, I I, I I I}$ in mining and geological environments on the parameters PI, II, III and UI, II, III of the fastening system of mine working, located in a homogeneous massif

It has been substantiated before that with the quite expected variation of action of the geomechanics factors along the length of mine working, it is the most expedient (from the point of view of load minimization) to assign to the fastening system the value of yielding property, which corresponds to the optimal value for the upper boundary (complex mining and geological environments) of the range of geomechanics factors fluctuation.

These optimal values of yielding property $u_{I}$ and $u_{I I, I I I}$, which correspond to the coordinates of points $A^{\prime \prime}$ and $A^{\prime \prime \prime}$ for all three change ranges in mining and geological environments $Y_{I}, Y_{I I}$ and $Y_{I I I}$, (Fig. 2). At the same time, the amplitude of geomechanics factors fluctuations (ranges $Y_{I I}$ and $Y_{I I I}$ ) does not influence on the choice of a rational yielding property $u_{I I, I I I}$ of the fastening system, if they have a common upper boundary on the complex environments parameters. Another conclusion is that the lower boundary of the intervals $Y_{I}, Y_{I I}$ and $Y_{I I I}$ (favourable environments) does not influence on the choice of rational yielding property of the fastening system based on the following considerations. The 2 ' line (load from the arch of ultimate equilibrium) is always located (along the vertical coordinate $P$ ) below the 2 " line, which, in turn, is located below the $2^{\prime \prime \prime}$ line. Therefore, if to consider, for example, the vertical from the $u_{I I, I I I}$ marker, then the minimum possible load value $P_{I I, I I I}$ (point $A^{\prime \prime \prime}$ ) will always be higher than the load determined by the points of intersection of this vertical with the lines $2^{\prime \prime}$ and $2^{\prime}$ (Fig. 2).

This conclusion emphasizes the significance of the upper boundary of the change ranges in geomechanics factors, but with account of the assumption about homogeneity of massif surrounding the mine working and the absence of the stope works influence.

\section{INTERACTION OF A SUPPORT IN THE PREPARATORY MINE WORKING WITH A HOMOGENEOUS MASSIF}

Accounting for the stope works influence intensifies the rock pressure manifestations and can be attributed to a number of factors complicating the mining and geological environments of maintaining the extraction mine working. This is indicated by the normative document (Weijian \& Genshui, 2017; Niedbalski, Małkowski, \& Majcherczyk, 2018), according to which the dimensions of the dome of natural equilibrium and the load from the weight of rocks inside of it are constantly growing, as the longwall face approaches and recedes. This circumstance in the studied diagrams can be accounted for with another line of family 2 , located above the rest, which makes it possible to use the above arguments for the preparatory mine working, which is influenced by the stope works.

As regard to the inhomogeneity of the structure of the coal-bearing stratum, it should be noted that accounting of it is possible in the described optimization approach with the modes of interaction between the fastening system and the surrounding massif (Kuttykadamov, Rysbekov, Milev, Ystykul, \& Bektur, 2016). However, the parameters of the families of lines 1 and 2 undergo a series of changes conditioned by the processes of stratification and collapse of the roof rocks above the drift and in the mined-out space.

Three variants of the roof rocks structure, significantly different from each other, are considered:

- a very thick and hard rock layer is depositing above the immediate roof, practically excluding the further development of displacement in the coal-overlaying formation (a bridge of rocks);

- a quite hard rock layer with medium thickness is in the main roof;

- the mostly thin layers with low thickness occur in the main roof.

The results of the SSS research of the roof rocks structure (Fig. 5) are the basis for the diagram development of formation a load $P_{1,2,3}$ on the fastening system of the preparatory mine working in all three variants of the main roof rocks structure. This diagram is represented in Figure 6.

For the first variant of the structure, the development of two factors ( 1 and 2 lines) of the fastening system loading is shown by full lines; their differences from a homogeneous massif are as follows. In the area with a low yielding property value $u$ of the fastening system (respectively, with insignificant displacements of mine working rock contour), the 1 line (the pressure of rocks increasing in volume) is different from that for a homogeneous massif only in some fluctuations with respect to the main "smooth" function $P(u)$, which describe the process of cracking and loosening of rock benches relatively each other throughout the thickness of the immediate roof.

When the displacements $u_{B 1}$ have compensated for the increase in the volume of the immediate roof rocks $\left(B_{1}\right.$ point), there was nothing left for loading the fastening system with yielding property $u_{B 1}$, since a very stable rock layer lies above (high thickness and high strength).

Then the load $P_{B 1}$ decreases sharply, and a low 1 line inclination characterizes the insignificant displacements during bending a rigid rock layer of the main roof. 
(a)

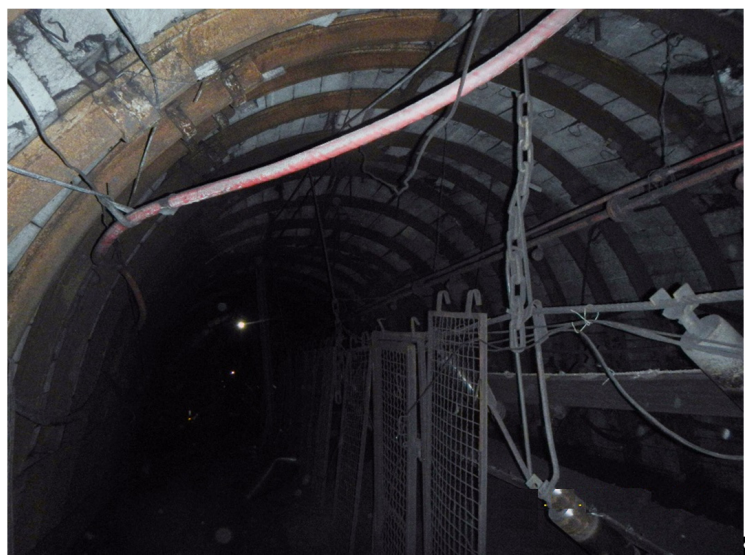

(b)

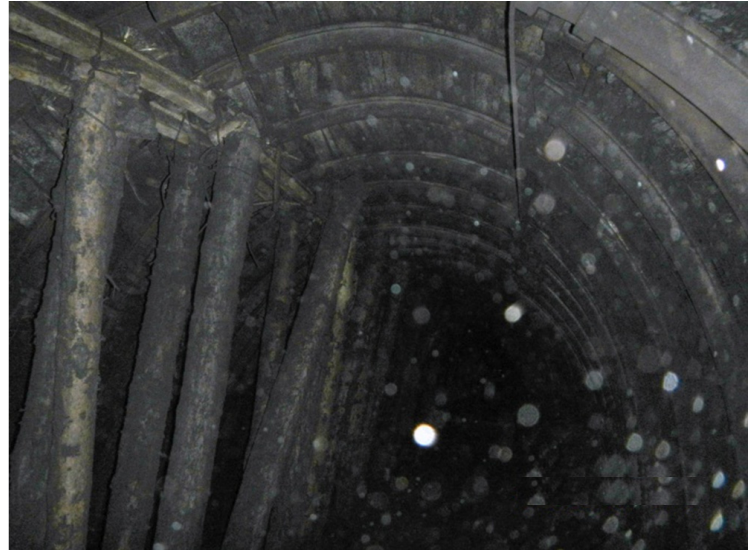

Figure 3. The fragments of state of the prefabricated drift in favourable mining and geological environments outside (a) and in the zone (b) of the stope works influence

(a)

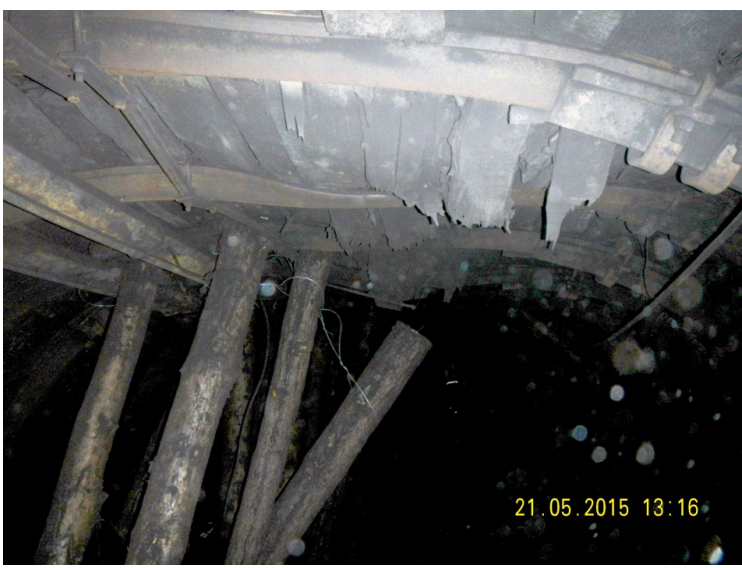

(b)

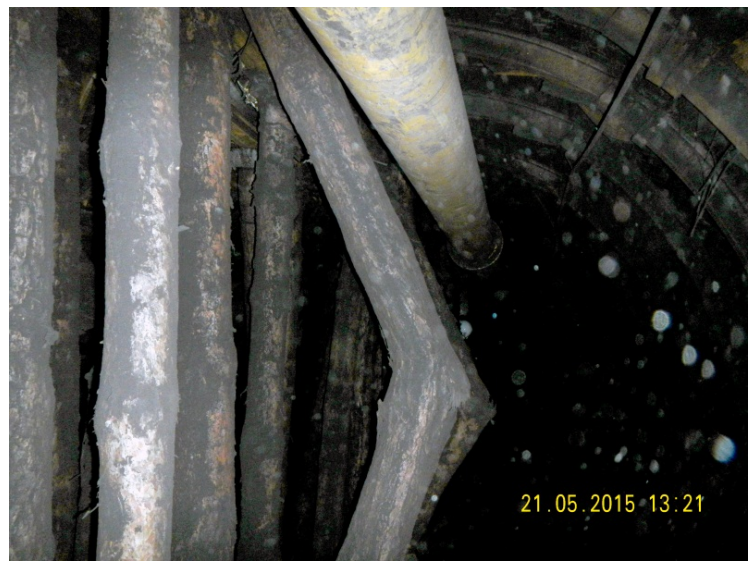

Figure 4. The fragments of the prefabricated drift state in complex mining and geological environments in the zone of the stope works influence: (a) flattening and plastic deformations of cap boards of the frame support; (b) destruction of the central (wooden) prop stays of the strengthening support

(a)

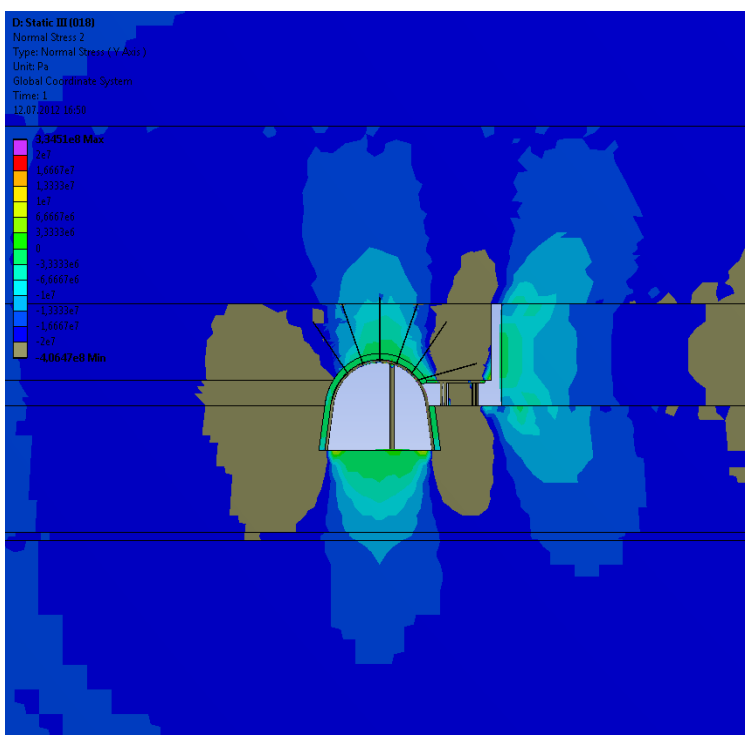

(b)

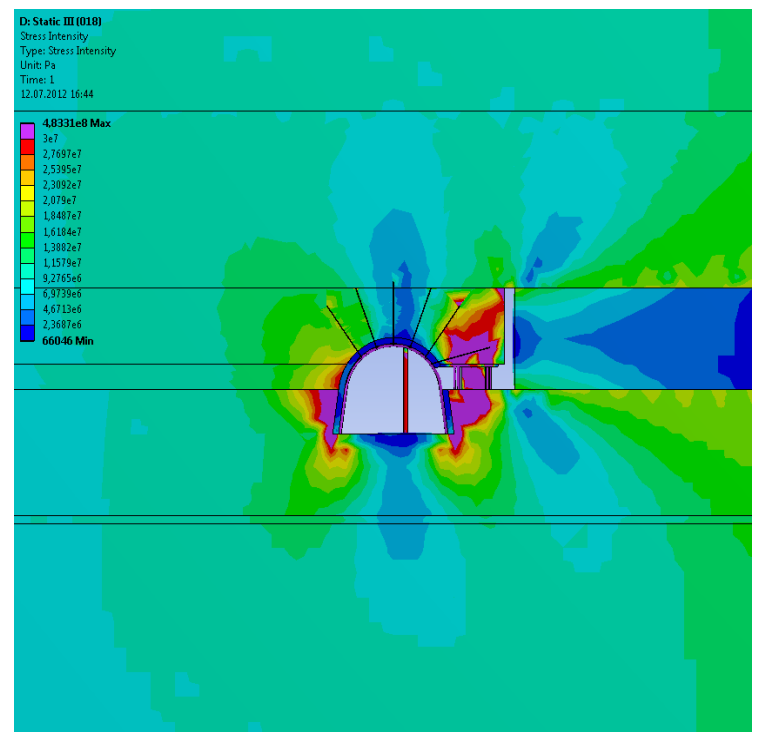

Figure 5. The fragments of curves of vertical (a) and stresses intensity (b) in the rock massif in the area of rock pressure stabilization behind the longwall face with a sufficiently hard rock layer with medium thickness (averaged stability) 


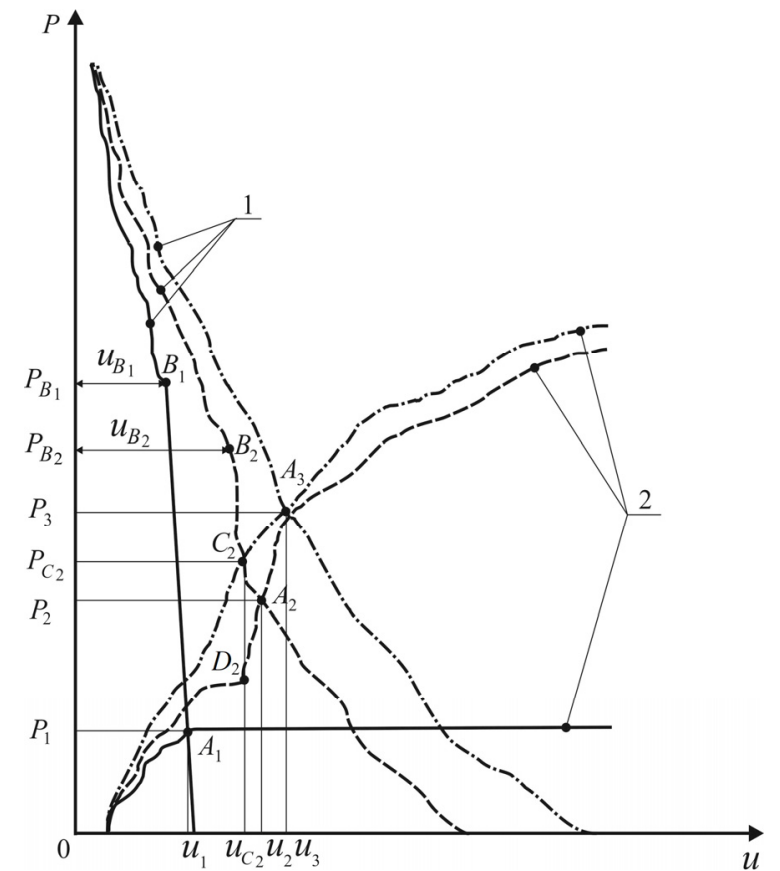

— a thick hard layer; - - a relatively hard layer with medium thickness; $-\cdot-$ thin-bedded and soft layers with medium thickness

Figure 6. The diagram of interaction of the fastening system in the preparatory mine working (in the zone of the stope works influence) with inhomogeneous coaloverlaying formation when in the roof it is occur: 1 -deformation-strength characteristics of the weakening massif; 2 -deformation-strength characteristics of the rocks of dome of natural equilibrium

Therefore, according to the factor of pattern 1 , the load on the fastening system can be almost completely avoided if its yielding property is slightly more than the value $u_{B 1}$; in this variant, the fastening system is completely protected by a very thick and hard rock layer of the main roof

The 2 line of the considered variant describes the formation of the load from the weight of rocks inside of the dome of natural equilibrium. At insignificant displacements $u \leq u_{B 1}$, the function $P(u)$ increases with low fluctuations characterizing the process of loosening and collapse of rock benches within the thickness of the immediate roof. When the dome of natural equilibrium reaches the surface of thick and hard lithotype of the main roof, its further development is practically stopped; the height of the dome is stabilized at the level of the immediate roof rocks thickness, which is identical to flattening the $P(u)$ function of the 2 line to a position in parallel to the coordinate $u$ (Fig. 6). The point $A_{1}$ of 1 and 2 lines intersection marks the optimal values of $P_{1}$ reaction and $u_{1}$ yielding property of the fastening system; respectively, the function of its deformation-strength characteristics $q(u)$ should be adjusted so that it passes through $A_{1}$ point.

As can be seen from the diagram in Figure 6, the first variant of the main roof rocks structure is different in the formation of the lowest load $P_{1}$ with an insignificant yielding property $u_{1}$ of the fastening system, which is quite natural: the fastening system takes up the load only from the weight of the immediate roof rocks, and the overwhelming part of the rock pressure is taken up by a thick and hard rock layer of the main roof.
Therefore, in such conditions, it is advisable to use a sufficiently rigid fastening system at a relatively low load-bearing capacity. The process of formation of a load on the fastening system in the second variant of the main roof rocks structure is reflected by 1 and 2 dashed lines in the diagram in Figure 6 . The relatively hard rock layer with medium thickness, constituting the structure of the main roof, restricts to a certain extent the process of stratification and weakening of the overlying rocks; thus, the 1 line is located near the same 1 line for the previous variant of the main roof rocks structure. Nevertheless, the rigidity of a relatively hard layer in the second variant of the structure is much less than in the first variant (the decrease in rigidity is proportional to the squared thickness): its own bending increases the lowering of the rock contour of mine working, to which some stratification of the overlying rocks is added due to the decreased rigidity of the hard layer. As a result, the displacements value $u_{B 2}$ exceeds the value $u_{B 1}$, and the $B_{2}$ point is located below the $B_{1}$ point (Fig. 6). Even as for the 1 line, the situation is similar to the first variant of the roof rocks structure: the lowering $u_{B 2}$ has compensated for all the displacements conditioned by stratification and an increase in the volume of not only the immediate roof rocks, but also the rock volumes occurring above a relatively hard layer with medium thickness.

If the yielding property of the fastening system is not less than the value $u_{B 2}$, then a load $P_{B 2}$ is acting on it, which falls sharply (almost vertically in the diagram) with an insignificant increase in the yielding property. The segment $B_{2} C_{2}$ of 1 line characterizes the period when a relatively hard layer withstands rock pressure and, thus, 'slows down' the stratification development in the overlying massif. But, at a certain point of time, a load-bearing capacity of the relatively hard layer is not enough to withstand the weight of the rock cantilevers from the side of mined-out space, the formation of which is developed throughout the height of massif. This point of time corresponds to $C_{2}$ point: the relatively hard rock layer with medium thickness is being destroyed, the lowering of the roof rocks increases, including due to the weakening of the overlying massif, and this is reflected in the more flat segment of 1 line up to the horizontal axis of $u$ coordinate.

The 2 dashed line, which describes the development process of the dome of natural equilibrium, is also transformed. At the initial stage of displacements development, the 2 dashed line is close to the 2 full line, and its low amplitude fluctuations with respect to the smooth function $P(u)$ are conditioned by the gradual loosening and loss of rock benches stability throughout the thickness of the immediate roof rocks. Some shift of the 2 dashed line to the left relative to the 2 full line is explained by the somewhat lowered rigidity of the hard layer (second variant of the structure) of the main roof, which loads the immediate roof and intensifies the occurrence of its unstable state.

When the dome reaches the hard layer of the main roof, the load increment is practically stopped (for a given period of time, the relatively hard rock layer is in a stable state) and the 2 dashed line flattens almost in parallel to $u$ axis. This load stabilization (by factor of the 2 line) occurs up to the point ( $D_{2}$ point) when a load- 
bearing capacity of the hard rock layer is exhausted; its resistance is no longer enough to withstand the growing volume of overlying unstable rocks; a collapse happens relatively hard rock layer with medium thickness that causes a sharp increase in dimensions of the dome of natural equilibrium and load volume on the fastening system. After stability loss with respect to a hard rock layer, the development of a dome of natural equilibrium determines the process of gradual loosening and collapse of the overlying rock layers of the main roof, which is decaying and ceases at a certain height from the contour of extraction mine working.

As before, the minimum of $P_{2}$ load on the fastening system (with its yielding property $u_{2}$ ) is determined by $A_{2}$ point of intersection of 1 and 2 dashed lines (Fig. 2). The $P_{2}$ value is naturally higher than the $P_{1}$ value, and the yielding property of the fastening system must be increased $\left(u_{2}>u_{1}\right)$, which is connected with the occurrence in the main roof of a less stable relatively hard layer. The question arises here about the rationality of $q(u)$ function of the deformation-strength characteristics of the fastening system, which passes through the $A_{2}$ point. On the one hand, the load $P_{2}$ is minimal, but the collapse is admitted of a relatively hard rock layer with medium thickness, as well as an activation of the growth of the dome of natural equilibrium. The development of rock pressure manifestations is ambiguous with the further maintenance of mine working, taking into account the action of both the rheological factor and other possible geomechanics phenomena that weaken the coal-bearing stratum. On the other hand, if to restrict the yielding property of the fastening system, for example, by value $u_{\mathrm{C} 2}<u_{2}$ (in order to prevent a collapse of a relatively hard rock layer), then its increased reaction $P_{C 2}>P_{2}$ will be required (Fig. 6). The solution to this controversial question was obtained when studying the mutual influence of the operation modes of fastening elements and the appropriateness of a two-level border and deep-earth strengthening of roof rocks with combined roof-bolting systems.

The third variant of the main roof rocks structure, represented predominantly by a thin-bedded structure (1 and 2 dot-and-dash lines), in terms of the modes optimization of interaction with a fastening system, is very similar to the previously considered optimization diagrams for a homogeneous massif. The differences are that 1 and 2 lines do not represent smooth functions $P(u)$, but are a combination with low amplitude fluctuations around these smooth functions. These fluctuations are conditioned by gradual loosening and collapse of rock benches inside the layer, or the entire lithological difference as a whole. The pattern is such that the thinner the layers or rock benches subjected to collapsing, the smaller the amplitude of 1 and 2 lines fluctuations and the higher their frequency. In the limit with a very thinbedded massif or its intense fracturing, the range of 1 and 2 lines fluctuations is reduced to insignificant, and the optimization dependences themselves almost coincide with those for a homogeneous massif.

Summing up the concepts about the modes optimization of the interaction between the fastening system of the preparatory mine working and the laminal coal-bearing stratum in the zone of the stope works influence, the fol- lowing should be noted. With regard to the mining and geological environments in Western Donbas, the thick and relatively homogeneous stratum (without evident stratification and with a large distance between the planes of weakening) of lithotype occurs in the main roof quite rarely. As for the strength characteristics, the hardest sandstone at best belongs to the category of rocks with medium strength (no more than 5-6 units by the scale of prof. M.M. Protodiakonov), but its thickness is restricted, as a rule, by several meters (SOU, 2007). Therefore, the first of the variants of the main roof rocks structure in the diagram of Figure 6 is not typical for the Western Donbas environments, but can be found in other geological and industrial regions. Thus, the first variant of the structure is not explicitly applicable, but a certain "intermediate" case between the first and second structure variants can be used for a general understanding of the mechanism for forming the load on the fastening system of mine working, as well as the principles of its minimization.

The third variant of occurrence of predominantly thin-bedded roof structure is more common in the Western Donbas environments, because of the fact that the rock layers with medium and higher thickness as part of coal-overlaying formation have an evident stratification inside the lithotypes and are easily divided into rock benches in the process of their displacement into the cavity of mine working and into mined-out space. The third variant of the structure is characterized by the maximum value of the optimal load $P_{3}$ at an increased yielding property $\mathrm{u}_{3}$ of the fastening system from the viewpoint of its modes optimization of interaction with the surrounding massif.

\section{THE INFLUENCE OF THE HEIGHT OF LOCATION OF THE LITHOTYPE WITH MEAN STABILITY ON THE LOADING OF MINE WORKING SUPPORT}

The second variant of the main roof rocks structure takes an intermediate position and also has a sufficient distribution in the Western Donbas environments. Here, it is necessary to keep in mind two equivalent situations: the occurrence of either a relatively hard layer with medium thickness, or a less hard but very thick rock layer with a large distance between the planes of weakening. In terms of the modes optimization of the fastening system operation, the variants of its deformation-strength characteristics $q(u)$ are possible, somewhat different from the optimal values $P_{2}$ and $u_{2}$, as it was described earlier. On the other hand, the occurrence of the rock layer with mean stability at a certain height from the mine working can be the reason for stopping the development process of the dome of natural equilibrium and the general stabilization of the rock pressure manifestations. Therefore, in our opinion, it is expedient to specify (or detailing) the degree of influence of the height $h_{i}$ of location of the rock layer with mean stability (the second variant of the main roof structure) on the process of load formation on the fastening system. For this purpose, a diagram has been constructed of two factors of loading the fastening system ( 1 and 2 lines) acting at different height $h_{i}$ of location of the rock layer with mean stability from the mine working contour (Fig 7). 


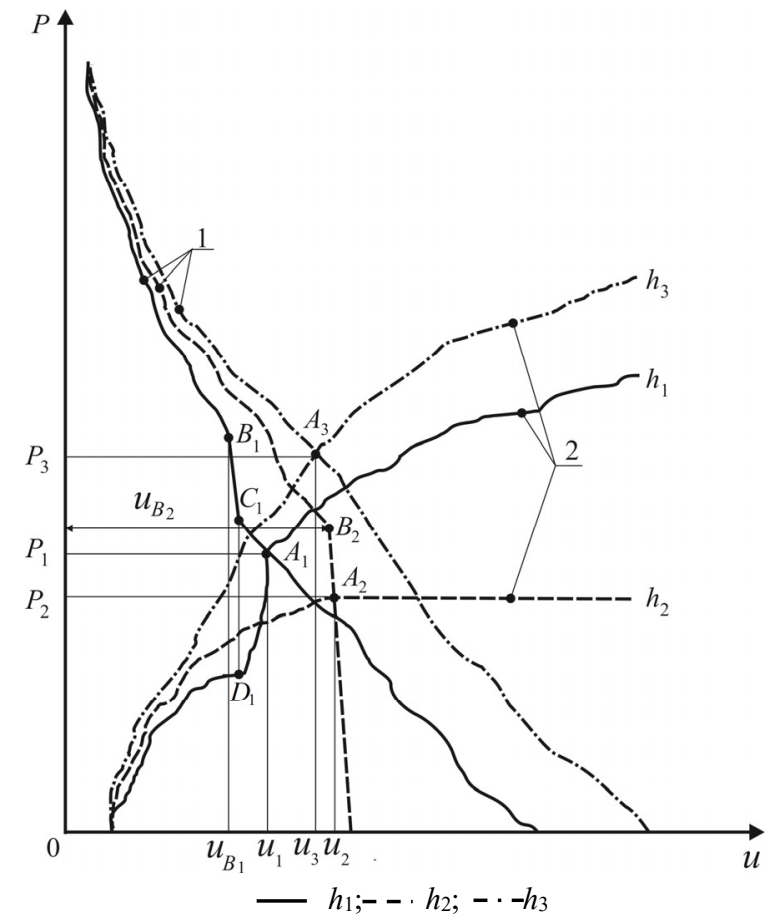

Figure 7. The diagram for assessing the influence of height $h_{i}$ of location of the rock layer with mean stability $\left(h_{1}<h_{2}<h_{3}\right)$ on the process of loading the preparatory mine working: 1 -deformation-strength characteristics of the weakening massif; 2-deformation-strength characteristics of the rocks of dome of natural equilibrium

In the first case, the rock layer with mean stability occurs immediately above the immediate roof at the minimum height $h_{1}$ from the mine working contour ( 1 and 2 full lines in Fig. 7). The line 1 characterizes the factor of stratification, weakening $u$, and ultimately, an increase in the volume of immediate roof rocks to $B_{1}$ point. This excess volume of rocks is compensated by the yielding property $u_{B 1}$ of the fastening system, and then an increase in displacements is insignificant, since the studied rock layer with mean stability takes up the rock pressure from the overlying massif. Therefore, with minimal additional roof lowering, the load (along the 1 line) decreases sharply to $C_{1}$ point, which characterizes the beginning of the weakening process of the rock layer with mean stability, and then its subsequent collapse under the influence of increasing rock pressure. Again, it is necessary to compensate for the growing additional volumes of weakening rocks from both the rock layer with mean stability and the overlying massif; the 1 line is flattening relative to the horizontal coordinate $u$.

For this case, the full 2 line has the following characteristic areas:

- to a value of displacements $u_{B 1}$ (vertical line from $B_{1}$ point), there is the development of a dome of natural equilibrium within the immediate roof thickness;

- further to the $D_{1}$ point, the development a dome of natural equilibrium is ceased, since the overlying rock layer is in a stable state;

- after its stability disturbance (to the right from $D_{1}$ point), the increase in dimensions of the dome of natural equilibrium is resumed and the load from the weight of rocks inside the dome increases sharply.
Therein, the coordinates $\left(P_{1}\right.$ and $\left.u_{1}\right)$ of $A_{1}$ point of 1 and 2 lines intersection can characterize the formation of a sufficiently high optimal load $P_{1}$, because the rock layer with mean stability, located close to mine working, has not performed its functions of at least partial protection of the fastening system from excessive rock pressure. With such a structure of roof rocks, it is possible to strengthen this rock layer with combined roof-bolting systems to a level providing maintenance of its stability (Fig. 8).

(a)

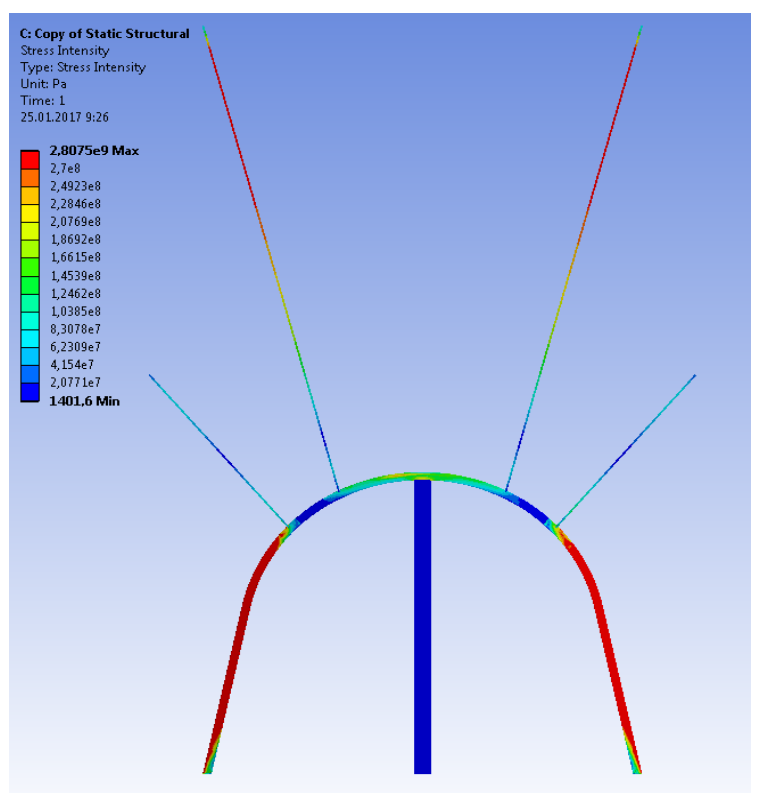

(b)

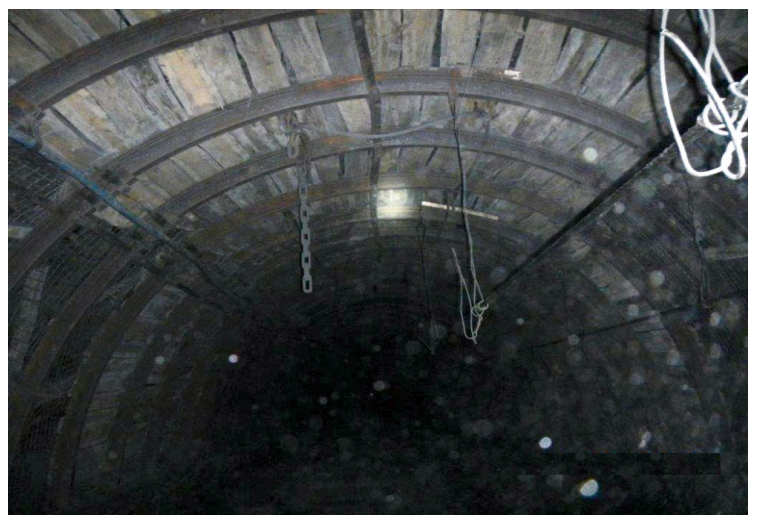

Figure 8. The fragments of curve of stresses intensity of the fastening system in the preparatory mine working (a) and its state (b) when strengthening the roof rocks by the combined roof-bolting system

In the second case of a more distant location of the rock layer with mean stability at a height $h_{2}$ from the mine working contour, the 1 and 2 lines are indicated as dashed and are characterized by the following peculiarities (Fig. 7). Since a stable rock layer is at a greater distance from the mine working contour, then an increased volume of underlying weakening rocks creates an increased lowering of the rock contour $u_{B 2}$ ( $B_{2}$ point on 1 line). Further, there is a sharp 1 line drop up to $P=0$, since the value of an additional increase in the volume of weakening rocks is exhausted, and the rock layer with mean stability is in a 
holistic state. Because of its greater distance $h_{2}$ from the mine working contour, the volume of unstable overlying rocks decreases and the load from their weight cannot destroy the studied rock layer with mean stability; therefore, in this case, it performs the functions of partial protection of fastening system from the rock pressure.

The dashed 2 line describes the increase in the dimensions of dome of natural equilibrium until it reaches the coordinates of location of the rock layer with mean stability. Then the increase in the dimensions of the dome is ceased, since the remaining part of the rock pressure is taken up by the rock layer with mean stability (the 2 line is in parallel to the horizontal axis $u$ ). In this case, the $A_{2}$ point of intersection of 1 and 2 lines is in a very 'appropriate' area of the load $P$ decrease along the 1 line and load stabilization along the 2 line. As a result, the optimal load $P_{2}$ is less than the optimal load $P_{1}$, that is, the location of the rock layer with mean stability at a greater height from the mine working contour is more expedient from the point of view of forming the minimum load on the fastening system in preparatory mine working. Furthermore, a larger part of this volume is not involved in formation of a load on the fastening system with strengthening the rocks by roof-bolting inside of the stable dome of natural equilibrium; then, the 2 line will be located much lower and the load value $P_{2}$ will be decreased many times. The question is to give an outline of set of conditions when this effect of the reduced load $P_{2}$ formation is present and to choose according to it the rational deformation-strength characteristics of the fastening system.

Finally, the third case assumes the most distant location of the rock layer with mean stability ( 1 and 2 dot-anddash lines in Fig. 7), when the height of the dome of natural equilibrium does not reach its borders. For this reason, the degree of the layer stability does not influence on the process of the load formation, but mainly the thin-bedded structure of the roof rocks in its behaviour is similar to the behaviour of a homogeneous massif. In the studied case, the factors restricting the process of roof rocks displacement do not act and therefore the value of optimum load $P_{3}$ will be maximum. The differences in the behaviour of a predominantly thin-bedded structure are only in some periodic deviations (from the general pattern) conditioned by the gradual loosening and collapse of rock benches inside the layer or the entire layer as a whole.

\section{CONCLUSIONS}

Summing up the generalization results on the concepts about the mechanism of formation of the load on the fastening system in terms of its rational deformationstrength characteristics choice and the influence of the main geomechanics factors on this process, it is necessary to focus on the following positions.

The essence of the process for a homogeneous massif around a single mine working and a soft thin-bedded massif in the vicinity of preparatory mine working in the zone of the stope works influence is quite similar in terms of influence patterns of the two main trends (families of 1 and 2 lines) of loading the fastening system. Moreover, in certain mining and geological environments, the qualitative differences are minimal and conditioned by account of the gradual stratification and collapse of the lithotypes constituting the roof rocks structure. Therefore, the gained concepts about the operation modes optimization of a support in the single mine workings should be used for the same purposes, but in relation to the preparatory mine workings in the zone of the stope works influence.

The patterns of geomechanics factors influence (on the choice of rational modes for the fastening system operation) create for the same mine working a certain range of changes in the interaction parameters with the surrounding massif, leading to a somewhat uncertainty of the optimization process of these parameters. The analysis of the set of variants for rational values of load on the fastening system and its yielding property have been schematically substantiated by the principle of the load minimization as the equality of two factors of its formation for the upper boundary of mining and geological environments characterizing the combination of the most unfavourable geomechanics parameters. The change range of geomechanics parameters and the corresponding mining and geological environments does not have a decisive significance, provided that the upper boundary is constant for development of 1 and 2 patterns in the formation of a load on the fastening system.

The influence of the main roof rocks structure is assessed as ambiguous: the predominantly thin-bedded structure and the variant of the closely adjacent relatively hard and thick rock layer at the initial stage of interaction with the fastening system behave differently, but in the process of further development of geomechanics processes of displacement in the coal-overlaying formation, the 1 and 2 patterns approach each other. Here, of particular importance is the location of the rock layer with increased stability relative to the mine working arch; in a certain range of changes in geomechanics factors, the maintenance of the continuity of the layer with increased stability provides a decrease in the load on the fastening system. The use of peculiarities of the main roof rocks structure in order to minimize the load on the fastening system has a wide perspective in terms of strengthening of rocks with combined roof-bolting systems.

\section{ACKNOWLEDGEMENTS}

The authors express their gratitude to the management of DTEK Coal Unit for their help in organizing the experimental research.

\section{REFERENCES}

Aitkazinova, S., Soltabaeva, S., Kyrgizbaeva, G., Rysbekov, K., \& Nurpeisova, M. (2016). Methodology of assessment and prediction of critical condition of natural-technical systems. International Multidisciplinary Scientific GeoConference Surveying Geology and Mining Ecology Management, 3-10. https://doi.org/10.5593/sgem2016/b22/s09.001

Arshadnejad, S. (2018). Determination of " $\mathrm{m}$ " in the HoekBrown failure criterion of rocks. Mining Science, (25), 125-141. https://doi.org/10.5277/msc182509

Bondarenko, V., Kovalevs'ka, I., Svystun, R., \& Cherednichenko, Y. (2013). Optimal parameters of wall bolts computation in the united bearing system of extraction workings frame-bolt support. Annual Scientific-Technical CollectionMining of Mineral Deposits 2013, 5-9.

https://doi.org/10.1201/b16354-3 
Bondarenko, V.I., Kharin, Ye.N., Antoshchenko, N.I., \& Gasyuk, R.L. (2013). Basic scientific positions of forecast of the dynamics of methane release when mining the gas bearing coal seams. Naukovyi Visnyk Natsionalnoho Hirnychoho Universytetu, (5), 24-30.

Bondarenko, V., Kovalevs'ka, I., \& Cherednychenko, Y. (2010). Substantiation of design and installation technology of tubular rock bolts by explosive method. New Techniques and Technologies in Mining, 9-14. https://doi.org/10.1201/b11329-3

Bondarenko, V., Kovalevs'ka, I., \& Fomychov, V. (2012). Features of carrying out experiment using finite-element method at multivariate calculation of "mine massif - combined support" system. Geomechanical Processes During Underground Mining - Proceedings of the School of Underground Mining, 7-13. https://doi.org/10.1201/b13157-3

Bondarenko, V., Kovalevskaya, I., Simanovich, G., Barabash, M., Snigur, V., \& Gusev, A. (2017). Kombinirovannye ankernye sistemy dlya povtornogo ispol'zovaniya gornykh vyrabotok. Dnipro: LizunovPres.

Bondarenko, V.I., Simanovich, G.A., Kovalevska, I.A., Fomichov, V.V., \& Serdiuk, V.P. (2007). Research of rock stresses and deformations around mining workings. Technical, Technological and Economic Aspects of Thin-Seams Coal Mining International Mining Forum 2007, 47-56. https://doi.org/10.1201/noe0415436700.ch6

Ivšinović, J. (2017). The analysis of water injection systems in sandstone hydrocarbon reservoirs, case study from the western part of the Sava Depression. Rudarsko Geolosko Naftni Zbornik, 32(1), 17-24. https://doi.org/10.17794/rgn2017.1.3

Khalymendyk, I., \& Baryshnikov, A. (2018). The mechanism of roadway deformation in conditions of laminated rocks. Journal of Sustainable Mining, 17(2), 41-47. https://doi.org/10.1016/j.jsm.2018.03.004

Kovalevska, I., Barabash, M., Husiev, O., \& Snihur, V. (2018). Interaction of deformation-strength characteristics of the support load-bearing elements in the preparatory workings. E3S Web of Conferences, (60), 00002. https://doi.org/10.1051/e3sconf/20186000002

Kovalevska, I., Symanovych, G., \& Fomychov, V. (2013). Research of stress-strain state of cracked coal-containing massif near-the-working area using finite elements technique. Annual Scientific-Technical Collection - Mining of Mineral Deposits 2013, 159-163. https://doi.org/10.1201/b16354-28

Kovalevskaya, I.A., Barabash, M.V., Snigur, V.G., \& Malova, O.K. (2018). Vliyanie peschanika na formirovanie anomaliy gornogo davleniya $\mathrm{V}$ pochve plasta, otrabatyvaemogo v svite pervym. Ugol' Ukrainy, (3), 12-16.

Kuttykadamov, M.E., Rysbekov, K.B., Milev, I., Ystykul, K.A., \& Bektur, B.K. (2016). Geodetic monitoring methods of high-rise constructions deformations with modern technologies application. Journal of Theoretical and Applied Information Technology, 93(1), 24-31.

Lozynskyi, V., Saik, P., Petlovanyi, M., Sai, K., \& Malanchuk, Z. (2018). Analytical research of the stress-deformed state in the rock massif around faulting. International Journal of Engineering Research in Africa, (35), 77-88. https://doi.org/10.4028/www.scientific.net/jera.35.77

Madziarz, M. (2015). Improvements in methods for monitoring anchor casings in mining excavations of KGHM Polska Miedź S.A. mines. Mining Science, (22), 115-125. https://doi.org/10.5277/msc152210

Małkowski, P., \& Ostrowski, Ł. (2017). The methodology for the Young modulus derivation for rocks and its value. Procedia Engineering, (191), 134-141. https://doi.org/10.1016/j.proeng.2017.05.164

Małkowski, P., Ostrowski, Ł., \& Brodny, J. (2018). Analysis of Young's modulus for carboniferous sedimentary rocks and its relationship with uniaxial compressive strength using different methods of modulus determination. Journal of Sustainable Mining, 17(3), 145-157. https://doi.org/10.1016/j.jsm.2018.07.002

Masny, W., Prusek, S., \& Mutke, G. (2017). Numerical modeling of the dynamic load changes exerted on the support in the stress concentration zones. Procedia Engineering, (191), 894-899. https://doi.org/10.1016/j.proeng.2017.05.259

Menshov, O. \& Sukhorada, A. (2017). Basic theory and methodology of soil geophysics: the first results of application. Visnyk of V.N. Karazin Kharkiv National University. Series Geology, Geography, Ecology, (79), 35-39. https://doi.org/10.17721/1728-2713.79.05

Niedbalski, Z., Małkowski, P., \& Majcherczyk, T. (2018). Application of the NATM method in the road tunneling works in difficult geological conditions - The Carpathian flysch. Tunnelling and Underground Space Technology, (74), 41-59. https://doi.org/10.1016/j.tust.2018.01.003

Sadovenko, I., \& Tymoshchuk, V. (2013). Hydrogeodynamics of the contact surface "lining-saturated rocks" in opening mine working. Annual Scientific-Technical Collection Mining of Mineral Deposits 2013, 85-90. https://doi.org/10.1201/b16354-17

SOU 10.1.00185790.011:2007. (2007). Pidhotovchi vyrobky na polohykh plastakh. Vybir kriplennia, sposobiv $i$ zasobiv okhorony. Standart Minvuhlepromu Ukrainy. Donetsk: Donetskyi vuhilnyi instytut.

Symanovych, G., Demydov, M., \& Chervatuk, V. (2013). Influence mechanism of rock mass structure forming a stress on a face support. Annual Scientific-Technical Collection - Mining of Mineral Deposits 2013,77-81. https://doi.org/10.1201/b16354-15

Tereschuk, R., Grigoriev, O., Tokar, L., \& Tikhonenko, V. (2014). Control of stability of mine workings equipped with roof bolting. Progressive Technologies of Coal, Coalbed Methane, and Ores Mining, 411-415. https://doi.org/10.1201/b17547-70

Weijian, Yu., \& Genshui, Wu. (2017). Support parameters optimization and engineering application of roadway with broken-expand surrounding rock in deep. Mining Science, (24), 252-268. https://doi.org/10.5277/msc172415

\section{УЗАГАЛЬНЕННЯ ТЕНДЕНЦЙ ВПЛИВУ ГЕОМЕХАНІЧНИХ ФАКТОРІВ НА ВИБІР РЕЖИМІВ РОБОТИ КРІПИЛЬНОЇ СИСТЕМИ ПІДГОТОВЧИХ ВИРОБОК}

\section{I. Ковалевська, М. Журавков, В. Черватюк, О. Гусєв, В. Снігур}

Мета. Обгрунтування механізму навантаження кріплення підготовчої виробки для оптимізації іiі деформаційно-силових характеристик на базі розрахунку напружено-деформованого стану системи «масив - кріплення». Удосконалення малозатратних технологій кріплення і підтримки підготовчих виробок.

Методика. Аналіз режимів взаємодії елементів системи «масив - кріплення», виконаний за двопараметричною схемою оптимізації деформаційно-силових характеристик породного масиву і кріплення підготовчих виробок із 
використанням результатів досліджень напружено-деформованого стану системи методом скінченних елементів. Проведено порівняння обчислювального експерименту з шахтними інструментальними спостереженнями.

Результати. Обгрунтовано геомеханічну модель обчислювального експерименту з вибору режимів роботи кріпильної системи й методологію підходу для оптимізації процесу взаємодії масиву з кріпленням. Розроблено та проведено аналіз схем пошуку раціональних деформаційно-силових характеристик кріпильної системи підготовчої виробки з урахуванням впливу на цей процес основних геомеханічних факторів.

Наукова новизна. Встановлено закономірності впливу геомеханічних факторів на вибір раціональних режимів роботи вантажонесучих елементів кріплення системи і кріплення в цілому на основі вивчення напружено-деформованого стану системи «масив - кріплення». Обгрунтовано оптимізаційні принципи взаємодії на базі аналізу двопараметричної схеми взаємодії.

Практична значимість. Обгрунтовано широку перспективу зміцнення слабких порід покрівлі підготовчих виробок, що повторно використовуються, комбінованими анкерними системами, яка дозволяє реалізувати ресурсозберігаючі умови підтримки. Розрахунки виконано з урахуванням оптимізаційних критеріїв взаємодії масиву з кріпленням.

Ключові слова: гірський масив, підготовча виробка, кріплення, деформачійно-силова характеристика, навантаження, стійкість, геомеханічні фактори

\section{ОБОБЩЕНИЕ ТЕНДЕНЦИЙ ВЛИЯНИЯ ГЕОМЕХАНИЧЕСКИХ ФАКТОРОВ НА ВЫБОР РЕЖИМОВ РАБОТЫ КРЕПЕЖНОЙ СИСТЕМЫ ПОДГОТОВИТЕЛЬНЫХ ВЫРАБОТОК}

\section{И. Ковалевская, М. Журавков, В. Черватюк, А. Гусев, В. Снигур}

Цель. Обоснование механизма нагружения крепи подготовительной выработки для оптимизации ее деформационно-силовых характеристик на базе расчета напряженно-деформированного состояния системы «массив крепь». Усовершенствование малозатратных технологий крепления и поддержания подготовительных выработок.

Методика. Анализ режимов взаимодействия элементов системы «массив - крепь» выполнен по двухпараметрической схеме оптимизации деформационно-силовых характеристик породного массива и крепи подготовительных выработок с использованием результатов исследований напряженно-деформированного состояния системы методом конечных элементов. Проведено сравнение вычислительного эксперимента с шахтными инструментальными наблюдениями.

Результаты. Обоснована геомеханическая модель вычислительного эксперимента по выбору режимов работы крепежной системы и методология подхода для оптимизации процесса взаимодействия массива с крепью. Разработаны и проведен анализ схем поиска рациональных деформационно-силовых характеристик крепежной системы подготовительной выработки с учетом влияния на этот процесс основных геомеханических факторов.

Научная новизна. Установлены закономерности влияния геомеханических факторов на выбор рациональных режимов работы грузонесущих элементов крепежной системы и крепи в целом на базе исследования напряженно-деформированного состояния системы «массив - крепь». Обоснованы оптимизационные принципы взаимодействия на базе анализа двухпараметрической схемы взаимодействия.

Практическая значимость. Обоснована широкая перспектива упрочнения слабых пород кровли повторно используемых подготовительных выработок комбинированными анкерными системами, которая позволяет реализовать ресурсосберегающие условия поддержания. Расчеты выполнены с учетом оптимизационных критериев взаимодействия массива с крепью.

Ключевые слова: горный массив, подготовительная выработка, крепь, деформачионно-силовая характеристика, нагрузка, устойчивость, геомеханические факторы

\section{ARTICLE INFO}

Received: 28 November 2018

Accepted: 12 June 2019

Available online: 4 July 2019

\section{ABOUT AUTHORS}

Iryna Kovalevska, Doctor of Technical Sciences, Professor of the Underground Mining Department, Dnipro University of Technology, 19 Yavornytskoho Ave., 49005, Dnipro, Ukraine. E-mail: kovalevska i@yahoo.com

Mikhail Zhuravkov, Doctor of Physical and Mathematical Sciences, Head of the Department of Theoretical and Applied Mechanics, Belarusian State University, 4 Nezavisimosti Ave., 220030, Minsk, Belarus. E-mail: zhuravkov@bsu.by

Viktor Chervatiuk, Candidate of Technical Sciences, Deputy Director for Production of the LLC “DTEK Energy", 57 Lva Tolstoho St, 01032, Kyiv, Ukraine. E-mail: ChervatyukVG@dtek.com

Oleksandr Husiev, Candidate of Technical Sciences, Director of the MM “Dniprovske”, PJSC "DTEK Pavlohradvuhillia”, 76 Soborna Ave., 51400, Pavlohrad, Ukraine. E-mail: GusevAS@dtek.com

Vasyl Snihur, Candidate of Technical Sciences, Director of the MM "Heroiv Kosmosu", PJSC "DTEK Pavlohradvuhillia", 76 Soborna Ave., 51400, Pavlohrad, Ukraine. E-mail: SnigurVG@dtek.com 